\title{
A Review of Digital Serious Games for Tsunami Risk Communication
}

\author{
Steven Hawthorn $^{1}$, Rui Jesus ${ }^{1,2}$, Maria Ana Baptista ${ }^{2,3}$ \\ ${ }^{I}$ NOVA LINCS, Faculdade de Ciências e Tecnologia, Universidade NOVA de Lisboa \\ s.hawthorn@campus.fct.unl.pt \\ ${ }^{2,3}$ Instituto Superior de Engenharia de Lisboa, Instituto Politécnico de Lisboa \\ rui.jesus@isel.pt \\ ${ }^{3}$ Instituto Dom Luiz, Faculdade de Ciências da Universidade de Lisboa \\ mavbaptista@gmail.com
}

\begin{abstract}
The research conducted a thorough review of evidence and effectiveness of digital serious games (SGs) for communication of action-oriented key messages (related to tsunami evacuation) to children. Significant scientific research investigates tsunami risk which is not always effectively communicated to children who are expected to make appropriate decisions during a tsunami event. SGs can motivate children and enhance risk communication. Computing technologies offer a delivery platform to access digital SGs which require little educator training and motivate learners. The research reviewed evidence of effective SGs that address tsunami risk and are deployable by educators. Based on this review, it is evident that very few suitable classroom deployable, digital SGs that address tsunami evacuation decision-making are available. Results showed only 2 suitable, available games. Similarly, while general evidence of the effectiveness of digital SGs was found, the evaluation of and evidence for the specific effectiveness of the available games was extremely limited. The education establishment and disaster community could exploit SG technology more effectively to communicate natural hazard risk to children in a global context where such risk is increasing. The research informs future game development projects which need to embrace comprehensive stakeholder involvement and inputs. Recommendations for serious game development projects are proposed.
\end{abstract}

Keywords: digital serious games, risk communication, tsunami evacuation, children;

\section{Introduction}

A key assumption in the disaster risk reduction process, is that people prepared prior to a hazard event are able to make potentially life-saving decisions when a hazard event occurs [1]. It follows that unprepared people are at higher risk of injury or death.

The ability of children to recognise natural warning signs demonstrates how key background knowledge of natural hazard characteristics helps make informed decisions and affect outcomes of dangerous events [2], [3], [4]. The application of theoretical knowledge to a real-world situation allows risk communication and persuasion of others to undertake lifesaving actions. The case demonstrates how childhood education allows informed decisionmaking and dissemination of risk messages to uninformed individuals (her parents). More formally stated, effective communication of disaster risks is critical to provoking appropriate responses from citizens and emergency operators [5]. These responses can literally become "life or death" decisions for people who find themselves in disaster situations. Risk communication methods vary greatly [6], but research suggests that a traditional knowledge transfer approach is not the most effective method of communicating risk [7], [8], [9]. It suggests that interactive and experiential methods are more effective at motivating learners 
pag. 22

about disaster reduction [10] than "spoon feeding" (which delivers information requiring no thought, responsibility or effort).

Digital SGs can be an effective way of providing interactive learning and experiential activities and thereby communicate tsunami risk more effectively than traditional, exercise book activities. This review aims to inform; 1) the educator community interested in using a tsunami related game in the classroom; and 2) the serious game development community who want to design and develop effective SGs for natural hazard risk and specifically tsunami risk communication. This paper is divided into two parts. In the first part, the primary objective is to assess evidence for the availability of SG for tsunami risk communication and, in particular, the understanding of natural warning signs of tsunami and training of decisionmaking skills for evacuations. In the second part, the objective is to assess the literature for evidence of effectiveness of SGs for communicating tsunami risk. That part will also consider the engagement characteristics of specific games from a learner's perspective, the suitability of the games from an educator's perspective and as a basis for classroom teaching, and further discursive debriefing activities.

\section{Availability of SGs for tsunami risk communication}

This section introduces the challenges of communicating risk before investigating which SGs exist for natural risk communication.

\subsection{Communicating risk}

Risk communication is an essential, but sometimes overlooked, activity in the stages of disaster management which can be incorporated into the mitigation stage of the disaster management cycle as general education and the preparedness stage as training or exercises. Imperative in the effective communication of risk is harmonisation around the message that will enable individuals to take appropriate action. The IFRC ${ }^{1}$ refer to these as action-oriented key messages [11], [12].

Submarine earthquakes are unpredictable and tsunami unstoppable once triggered. They move quickly to coastal settlements, some lacking operational warning systems, or as in the case of the Mentawai Islands 2010, a warning was issued, but it did not arrive in time due to limited communication network [13]. In such cases, effective decision-making relies on an individual's knowledge of the natural warning signs, which are characteristic of tsunami [11].

The natural warning signs are summarised by three words; feel, see and hear. Strong or moderate ground shaking felt for 40 seconds or more, indicates a high tsunami risk with limited time for official warning. The recommended action is to move to higher ground immediately. Individuals near the coast could see a rapid rise or fall in coastal waters, hear coastal water making unusual noise, like an approaching train, or hear a whistling sound [11], [12]. Methods of risk communication need to clearly communicate these key messages for individuals to enable them to make decisions about whether to evacuate, or rest in place.

${ }^{1}$ International Federation of Red Cross and Red Crescent Societies 


\subsubsection{Effective Risk Communication}

Risk communication is not new [14] and multiple definitions of risk communication exist [15], but central to the concept is the passage of information between parties. Risk communication herein focuses on education to equip individuals to recognise imminent hazard and inform appropriate decisions to reduce risk. In this case, timely evacuation prior to the arrival of the first wave. However, communicating risk effectively is not as simple as providing information in the form of probability values of hazard occurrence.

Early risk communication methods were based on the communication of a risk message [16], [9], and relied on the premise of a knowledge deficit between the scientifically informed experts and the lay public [17]. Referred to as the deficit model of risk communication, once the uninformed became informed, the risk has been communicated and (theoretically at least) the informed are capable of responding appropriately. The deficit model has been examined, debated and criticised following the publication of [18] which stimulated discussion about expert roles in science communication.

Interactive risk communication methods are preferred due to the active process that they facilitate, resulting in a departure from a sender/receiver concept to a two-way communication approach. Disaster information in isolation, although logically comprehensible, is meaningless [17]. Without action-oriented key messages the effectiveness of risk communication and subsequent decision appropriateness is greatly diminished. Risk communication can be counterproductive [20]. In the context of protection motivation theory [21], ill-conceived communications can heighten perception of flood risk without providing the information to equip users to establish positive threat and coping appraisals [18]. Interactive activities and discursive debriefing support the development of action plans and provide coping appraisals for learners.

Risk communication is increasingly effective as an interactive exchange-based process [20] rather than the delivery on an information product or service. It is clear that innovative methods (such as SG), that facilitate interactive communication need to be investigated for their effectiveness. Considering how learners process and understand risk information and the actions they can take is important and illustrate how SGs can increase the effectiveness of risk messages. As such, learning theories must be considered when discussing risk communication as part of the wider context of disaster risk education [12]. Typically, basic conceptual and theoretical knowledge of disasters and disaster prevention are transferred to learners by educators following the Cognitive, Skill-based, and Affective learning model [23]. Educators expect learners to translate the transferred knowledge into actionable skills and update their attitudes toward disaster prevention [7]. These expectations include response to disasters based raised awareness, assume knowledge retention, action plan development and appropriate decision-making in shocking and stressful conditions.

A review of research methodologies related to SGs, contrasted traditional 'fact transfer' approaches with a constructivist approach where knowledge is an emergent property of a construction / analysis / revision process. The constructivist approach rejects the simple transfer of facts as a way to provide knowledge and, by extension, knowledge transfer as a way of informing decision-making is considered insufficient [8], [24]. Therefore, to be effective, "teachers cannot simply transmit knowledge to students, but students need to actively construct knowledge in their own minds" [25, p. 66].

The process of knowledge development is helped by participatory, interactive and discursive activities which help develop the constructions and inform the revision process. This approach to learning is supported by interactive games that can model situations that are virtually impossible to re-create (such as a tsunami), but which are helpful in teaching decision making under uncertain, dynamic and stressful situations.

A review of information types (passive, interactive and experiential) on household preparation for earthquakes in New Zealand interactive activities, were particularly suitable for stimulating discussion, with experiential information having a significant impact on the preparedness process, [26]. This reinforces the contention that risk communication is more effective when passive information is combined with interactive and experiential information, 
and supports the contention that interaction within social and worldly contexts is important for understanding hazard information. It is reasonable to conclude that the effectiveness of the risk communication could be improved with activities which are interactive and "pseudo" experiential, such as SGs.

Another important consideration for effective communication is learner motivation. The "fact transfer" approach results in motivational challenges for learners and does not induce high levels of motivation [27]. Learners can become detached if their curiosity is not engaged, and observing someone else's experience results in a dilution effect which is not as resilient as their own experience [28].

However, SGs can provide learner motivation as an intrinsic property of gameplay and it is suggested that learners who are enjoying the experience learn more effectively [29]. It is reasonable to conclude that interactive approaches, combined with new technology, can provide new opportunities to engage learners in an interactive activities, combined with subsequent additional discursive and debriefing sessions, will improve the effectiveness of risk communication [30], [31]. It is the contention of this paper that SGs can be an effective tool in providing an environment where effective learning can take place.

\subsubsection{Children as risk communicators}

Children tend to suffer disproportionately during natural hazard events [32], [33], [34], and arguably should be equipped to make appropriate decisions where possible [5]. Formal education systems are a natural place to provide information and activities related to natural hazard risk [35] as children represent a 'captive audience' for activities that are guided, controlled and monitored by curriculum-based inputs. Teachers who may not be aware of actionable advice from specialist disaster agencies would also be updated through practice [36]. It also follows that the children of today are the teachers and parents of tomorrow with a responsibility to equip future generations in disaster preparedness.

A review of children's role in disaster scenarios suggest they children have a lot to contribute through their participation in disaster preparedness activities [37]. Conventional assumptions of adults as harmonious, community focused actors attuned to family needs, and children as passive victims were challenged. They concluded that children can act as conduits for communicating risk and have a significant role to play in disaster risk reduction, but stressed the need for functioning institutions on disaster risk reduction that are willing to be child centred to include the children's perspective [32].

The focus of this report is on school-aged children for two reasons. First, they are exceptionally vulnerable as the potential receivers of ineffective guidance and incompetent situation management. During the 2011 Japanese tsunami, school children in Kamaishi City survived, reportedly owing to effective preparation activities, including identification of evacuation routes and regular drills. In contrast, at Okawa Elementary School, 74 children died or disappeared, with suggestions that this was due to evacuation guidelines that were unclear [1], [38]. Second, there is a lack of research related to the effects of disaster communication on children [35] with suggestions that schools are suitable places for programmes outlining potential risks (contextualised in the learners' experience), and providing guidance on preparation for disaster situations.

\subsection{Serious games for risk communication}

Defining and classifying SGs is a non-trivial exercise. This section provides a brief overview of some related background and discussion. The original term "serious game" was used in 1970 [39], but has since been developed by others along the way. Sawyer [40] first coined the term "serious games" in the context of digital games when referring to a game for public policy making.

A comprehensive history of digital SGs was presented in [41] and was reassessed by Michael and Chen [42] as games whose primary purpose was not to entertain, but were suitable to inform, educate and train learners. They considered that the serious element related 
to these games refers to content that makes the games suitable for use in an education scenario. This could include games which are not formally classified as "serious" but are used to convey a serious concept or idea. In the case of a tsunami SG , the inclusion of valid action oriented key messages [11] designed to inform decision-making should be considered. Games have the potential to give misleading information to learners which could have undesirable consequences [43].

The concepts of play and game were thoroughly examined in [44] which also reviewed pervasive games that aim to develop games that integrate more completely with the real world. A summary of e-learning presented six theoretical perspectives for learning within an ICT context [45] with the term "Edugames" considered as games specifically developed with the purpose of transmitting educational knowledge. Game classifications initially used freeform groupings but developed to include game genres which although an important part of global video game culture, are too numerous and too specific to be used as a reference [46]. As such, they proposed a new classification model that combined the analysis of both "serious" and "game" dimensions in the Gameplay / Purpose / Scope model."

While definitions and terminology abound, the label attached to the game is less important than the way it is utilised. The seriousness can come from the context in which the game is played, not necessarily the genre, designed purpose or nature of the game itself. Often the seriousness of the game is associated with the game creator, designer or facilitator, but it needs reflect in the approach of the players. Learners can become very serious about seemingly trivial games (such as hangman) when competition is introduced, or fairness protocols are perceived to have been breached. Conversely, games related to serious subjects may not be taken seriously by players for a variety of reasons, so the term "serious games" remains imperfect.

Bente and Breuer questioned the oxymoronic nature of the term "serious game" and went on to investigate the relationship between SGs to other educational concepts like "edutainment" or "e-learning", where edutainment is largely focused on school and preschool children, whereas SGs games are also focused on older learners and adults. They remarked the learning mode in early edutainment programs was more about memorisation of facts and was therefore less interactive than SGs can be [47]. They contended that most game designers and researchers agree that SGs go beyond edutainment, and regard edutainment games as a subset of SGs [48], [49], [50].

However, it has been noted that as the SG industry includes interests from a wide range of diverse occupations including health, defence and advertising, therefore definitions are prone to territorial focus [51]. As their primary interest was education, they adopted a broader definition of SGs as any piece of software that combines a non-entertaining purpose (serious) with a video game structure (game).

As the focus of this research is using innovative computer technologies combined with interactive approaches to education, this definition for SGs is used in this article.

\subsubsection{Serious games applied to emergency scenarios}

The study initially adopted a broad view with studies focused on SG and simulations in escalating situations, followed by SG addressing natural hazards and finally more focused on tsunami SG with a view to informing evacuation decisions.

Simulations and SGs have been used in a diverse range of emergency training and escalating situation scenarios including combat training, [52], [53], [54], [55] healthcare training, [56], [57], industrial emergency management training, [58], and civil defence emergencies [59], [60]. However, military or medical emergency response personnel undertake training with a clear understanding that there is a high level of certainty they will have to apply their learning in an emergency situation. This explicit learning rather than stealth learning [61]. Schools learners do not necessarily perceive natural risk to be high and are prone to frivolousness, therefore the class management overhead is significantly reduced with professional adults. 
Evacuation scenarios have been the focus of SG from large crowd events [62] to singular buildings examples [63]. A review of fifteen SG in evacuation scenarios [64] revealed a significant gap between research on fire (11 papers) versus earthquake evacuation (1 paper). The majority of the studies used university students as participant, with only one study using an immersive virtual environment with children as research subjects [65]. The review recommended that more attention needs to be paid on earthquake safety training but made no explicit mention of tsunami evacuation [64].

A comprehensive overview of SGs for disaster risk management was undertaken by Solinska-nowak et al. [66], who identified 45 digital and analog non-commercial gaming activities involving disaster risk management. Of the 45 games, 5 were specific to tsunami hazard, and of those, 3 were computer-based games, Disaster Master, Stop Disasters and Earth Girl.

Other games included "face to face" analog board games designed to be played in groups. Significant ongoing work has been undertaken in this area, often with specialist groups such as risk professionals and policy makers [67], [68], [69]. These games are engaging, fun and informative, [70] but require a trained facilitator, reach a limited number of players (typically specialist professionals) and require significant preparation. These games are not commensurate with the gameplay experience of secondary school children. For these reasons they were not considered as part of this research.

\subsubsection{Method and results}

While the review adopted a systematic approach, it was not possible to use multiple reviewers and therefore does not meet the criteria for a strict systematic review. It was undertaken between August and October 2020 using the following data sources. Google Scholar was the primary online data source used due to its comprehensive coverage simple, advanced search feature and the general reliability of the research results retrieved [71]. The Publish or Perish software [72] was used to sort and select Google Scholar results.

The review attempted to ensure a balance between comprehensiveness of coverage, relevance and manageability of results and was designed to optimise recall by keeping the search terms as few and as relevant as possible. A multifaceted search included further investigation of relevant references in journals, as well as a manual search of the ISCRAM Digital Library. Searches did not specify excluded words, searched within the document text and included citations but not patents. The search terms used during the initial literature search are summarised in table 1, in the appendix. The intention for this review was to focus on digital SGs applied to communication of natural hazard risk, specifically related to tsunamis and to secondary school aged children (9-16). As such, the review was carried out under some specific review criteria summarised below;

1. It focused on articles published in peer reviewed journals, but also reviewed material including disaster agency reports and government reports.

2. It is only concerned with digital SGs which include some element of tsunami risk related to submarine earthquakes.

3. It is concerned with games designed for school aged (9-16) children for use by educators in a classroom situation. Games which are entertainment focused, contain a tsunami scenario (such as GTA5), but do not contain a learning component, are not included. Accounting for the educator's perspective, games should be accessible, preferably online, and require minimal setup, be supported with classroom materials such as handouts and quizzes, and facilitate post-game debrief activities.

4. It also excludes games designed for risk professionals, disaster agency workers and policy makers.

5. Importantly, the research is looking for games that contain information about natural warning signs in order to inform the evacuation decision-making process.

6. Because of the nature of digital games, some non-academic sources were searched. These included Google Play store, iTunes, Amazon store and YouTube. 


\subsubsection{Results}

The review found five serious digital games which include or are focused on tsunami risk communication. These are considered potentially deployable by educators in a school situation and could form the basis of classroom-based lessons or activities, and are summarised in the next section.

A number of tsunami SGs and simulations were retrieved that, although useful in a general sense would be challenging to deploy in a school environment. Some commercially developed games are available such as the Disaster Report Series, (Zettai Zetsumei Toshi in Japan) [73]. However, they require PlayStation consoles which are generally unavailable in schools, and that could be prohibitively costly for some learners living in some tsunami vulnerable countries. A number of tsunami focussed simulations both have been developed by university research teams [74], [75], [76], which provide interesting insights into potential evacuation behaviour, but have been developed with analysis in mind, are not easily accessible, require VR headsets which are not widely available in most schools and would prove challenging to deploy in a classroom situation. As an alternative, YouTube video of real tsunami events conveys the destructive characteristics of tsunami and is extremely easy for teachers to access and deploy. Tsunami Fighters is a collaborative tsunami SG which appears to offer a useful addition to tsunami SGs, however, at the time of writing it was not available for evaluation, [77]. As such, the applications summarised here, were not considered sufficiently deployable to be studied in further detail.

Due to the gaming related nature of the research, and as part of a multifaceted search, a number of non-academic sources were considered. A YouTube search was undertaken which retrieved videos related to tsunami gameplay commentaries. An informal review of the top twenty SEO ranked videos retrieved revealed the following; 5 tsunami videos using Cities Skylines; 3 showing Grand Theft Auto 5; 3 using Minecraft; 3 using Stormworks; 2 using Floating Sandbox; and 1 using Disaster Day of Crisis, Roblox, Tiny Town VR and Tomb Raider 2018 respectively. This was undertaken to identify potentially useful games not represented in the literature.

A search of Google Play store retrieved Quake Tsunami which is a jump and run tsunami escape game which offers limited educational value. A search of the iTunes store and Amazon produced numerous unrelated games including Zombie Tsunami and Sushi Tsunami. These videos games contain few if any key messages. Video footage of real tsunami events would provide a higher degree of educational and discursive value.

\subsubsection{Summary of games}

The following section outlines the general characteristics of the SGs retrieved during the review. "Stop Disasters" is included (even though it does not have an explicit evacuation concept) as it could be a useful game from which to initiate discussion.

Disaster Master (undated) is a graphic novel-based game designed for primary school aged children (6-11) and addresses 6 different natural hazards that can occur in the USA; wildfire, tornado, hurricane, fire, winter storm and tsunami/earthquake. It was developed by the United States Government in conjunction with FEMA, under the Ready.gov public education initiative. It is browser based and can be played on PC, MAC, Android and Tablet platforms. The game is available in English and Spanish.

It follows a graphic novel format, featuring a group of young people who meet at summer camp in Colorado and subsequently return to various parts of the United States. Each of them encounters some form of natural hazard. These hazards form the basis of one of the six levels in the game. Players follow the game narrative and have to answer questions. Successful answers score points and allow passage to the next level, using the password provided. Passwords are required if educators want to go directly to a specific level, to address a specific hazard scenario. Passwords are widely available on the internet.

In the tsunami scenario, the character offers help (as advice) but without delaying her own evacuation, thereby combining an altruistic and self-reliant philosophy. Players move 
pag. 28

between pages of the graphic novel and answer questions about the scenario. Correct answers are rewarded with points and provision of the password to the next level. There is no time constraint in the game, players can proceed as fast or slow as they prefer. The gameplay and graphics are rudimentary without sound effects.

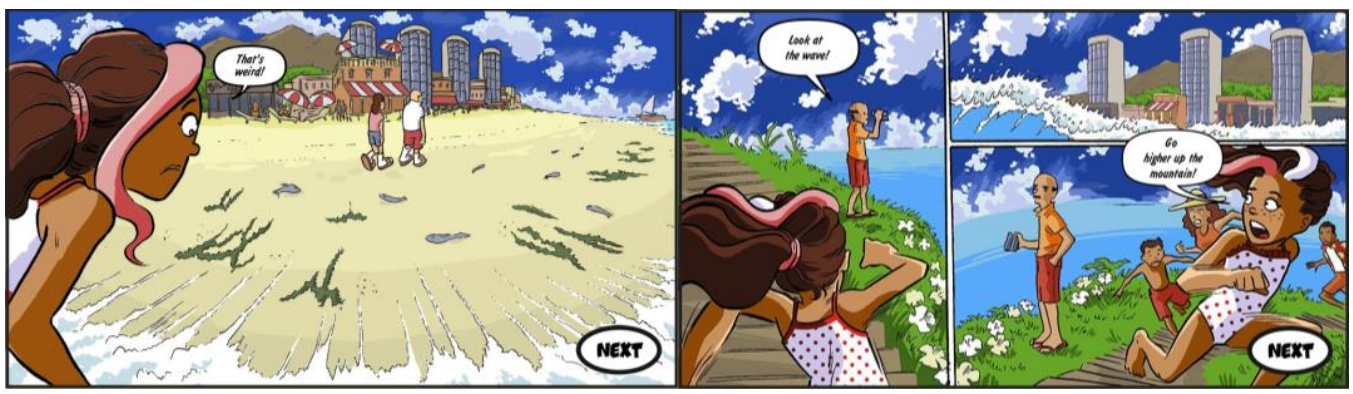

Figure 1. Screen captures from Disaster Master showing tsunami draw down and evacuation.

Stop Disasters (2007) is an "interactive educational tool for children aged 9-16" [78] which focusses on community urban planning as a way to reduce negative impacts of natural environmental hazards. It addresses 5 natural hazards (wildfires, earthquakes, floods, tsunamis and hurricanes) in different countries of the world. It was developed by the United Nations Office for Disaster Risk Reduction (UNDRR) in conjunction with Playerthree, a digital production company based in London, UK. The game is available in English, Spanish, Chinese, Russian and French. The game was released in 2007 and is XML driven, so it can be disseminated via the internet and only requires web browser software. It can also be played on PC, MAC, Android and Tablet hardware platforms.

Importantly, the concept of evacuation decision-making is not present in this game. It is focused on resilience planning for natural hazards from a community perspective. Players choose a hazard scenario and difficulty level and are presented with some introductory scene setting dialogue boxes which describe the background and objectives of the scenario.

Players then make decisions about the construction of buildings and infrastructure in the community that should protect the community members when disaster strikes. After a predetermined time, the hazard event occurs and, following the hazard event, players are provided with a mission report containing information about causalities and damage to buildings. The game has good quality graphics and follows the same gameplay each time. Passwords are not required for this game. The game includes sound effects which can be muted.
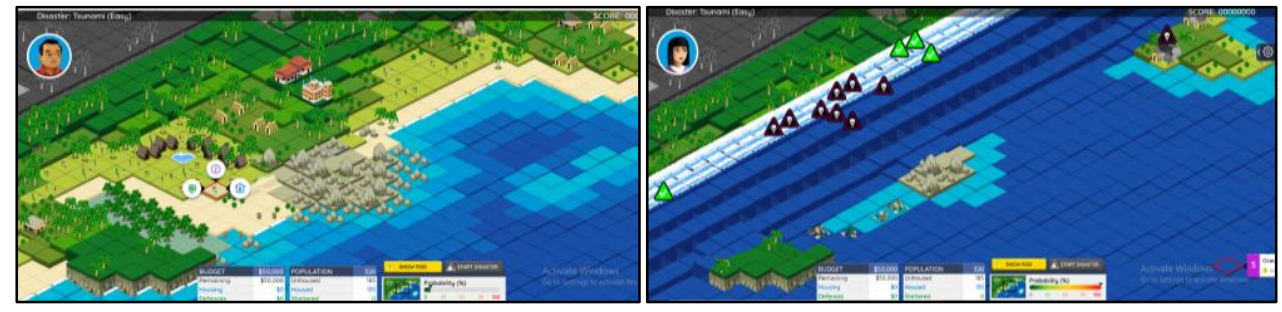

Figure 2. Screen captures from Stop Disasters - Planning for the tsunami and the tsunami strikes. 
Earth Girl (2011) and Earth Girl 2 (2014) are versions of the same game [79]. Both games use a $2 \mathrm{D}$ interactive format and features a principal dynamic, female character called Earth Girl who makes strategic decisions during an earthquake and subsequent tsunami scenario. The game primarily addresses tsunami hazard. It was designed for 8-15 year old learners [80] and was developed by scientists and game artists at the Earth Observatory of Singapore.

The review of Earth Girl 2 is limited because the author could not activate the game due to inactive html links on game pages [81] . A video demonstration of the game [82] showed the main concepts which involve speaking to villagers, investing in village infrastructure and effective evacuation of the village. Earth Girl 2 is available in English, Indonesian, Thai, Tamil and French. A volcano related version of the game is also available [83].

In the tsunami scenario, the original game allows Earth Girl to push other characters away from the beach which delays her own evacuation. This could form the basis of a classroombased discussion related to "Tendenko" philosophy. The character can also develop special powers to defeat the wave, including the ability to stun the tsunami with a force field. While fun and exciting, this provides an inaccurate message about how to behave when faced with tsunami hazard. There appears to be no time constraint in Earth Girl however, in Earth Girl 2 , there is a time indicator.

However, the tsunami game is unfortunately no longer available online due to technical issues (I. Kerlow, private communication, December 2020).
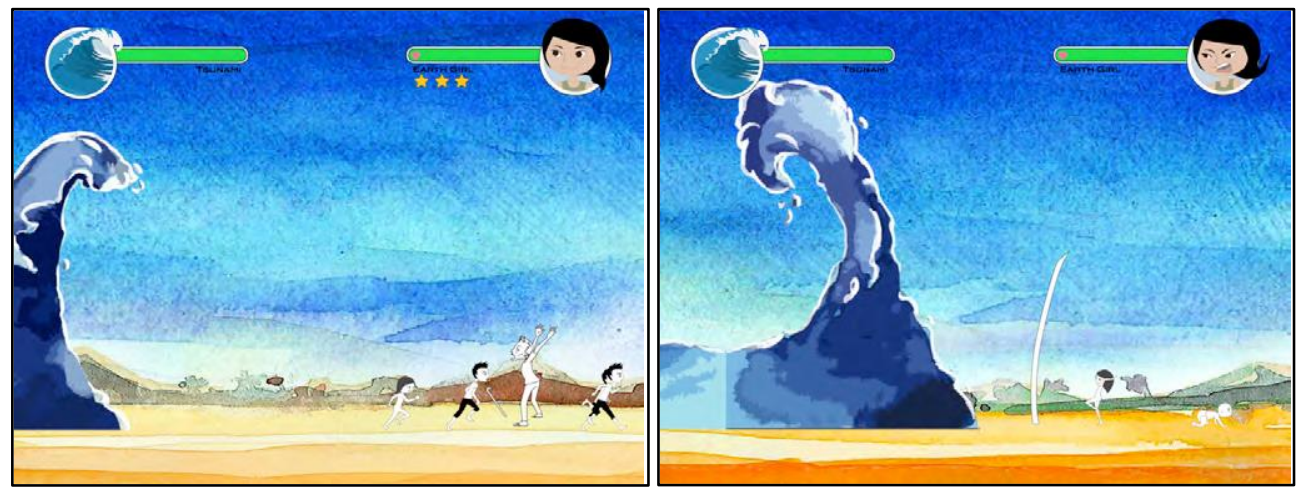

Figure 3. Screen captures from Earth Girl. On the left Earth Girl pushes the villagers away from the beach. On the left she stuns the tsunami with her special powers.
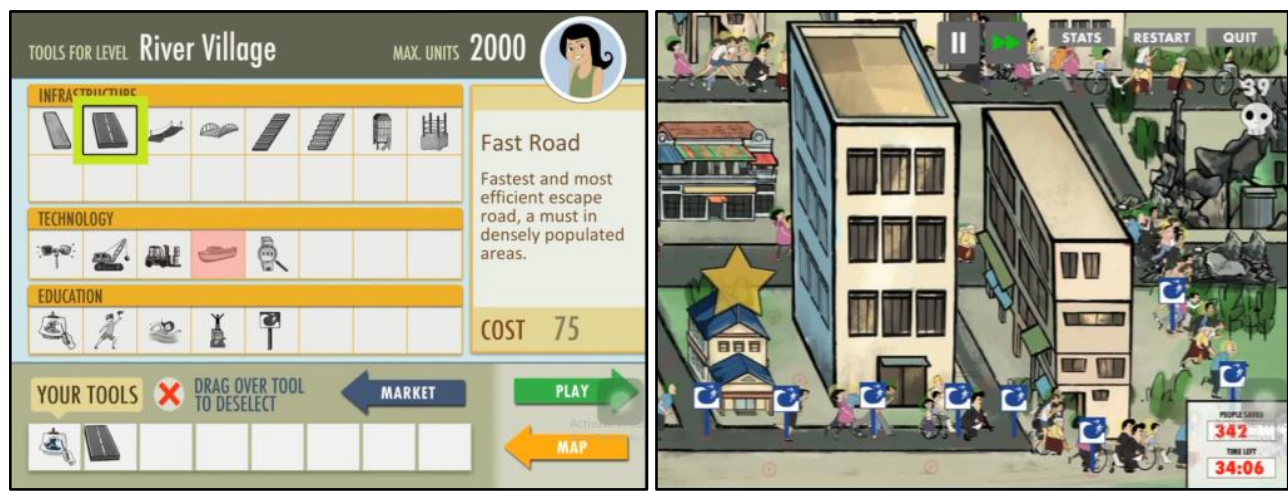

Figure 4. Screen captures from Earth Girl 2. The player can purchase tool, and invest in the village infrastructure which helps villages evacuate more effectively.

Tanah - The Tsunami and Earthquake Fighter (2015) was a collaborative project developed by Global Disaster Preparedness Centre, UNESCO-Bangkok, and USAID. It was 
pag. 30

supported by the Asian Coordinating Centre for Humanitarian Assistance on Disaster and Management and the Indonesian Red Cross Society [84].

Tanah is a 2D, platformer "jump and run" game developed by Opendream, published in 2015 featuring the principal character "Tanah", who moves to a new coastal town (which has a tsunami warning system) and prepares the house for future disasters. It appears to be aimed at younger secondary school children. The game is level based and covers a number of preparation activities before the tsunami occurs. It does not appear possible to skip forward to the tsunami stage of the game.

The game checks the player's knowledge of what they should do as the game proceeds, and features a supernatural element in the form of an ancient dragon creature, which urges Tanah to warn the villagers about the future earthquake.

During the tsunami stage of the game, Tanah finds that the tsunami system has been damaged and is inoperable. Tanah delays her own evacuation to help another character (the officer). She wants to help the villagers who will not get a warning because the system is damaged. This is very commendable but if they knew the natural warning signs, they would know that they needed to evacuate. When told to leave she says, "if I sense something bad, I'll run". Tanah follows the evacuation route and tsunami evacuation signs to the end, then looks for a suitable building to vertically evacuate. After the wave, Tanah looks for first aid materials to help injured people. This game does not clearly indicate the natural warning signs of tsunami explicitly. It is linked to the earthquake, but there is no mention of duration or strength of shaking, drawdown, sea noise, or concept of tsunamis coming in multiple waves. It can be played on PC but needs an Android emulator such as Bluestacks, which need to be downloaded and installed. Therefore, in a teaching scenario, it is most realistic to play this game on mobile phones. The game may best be suited to younger learners.

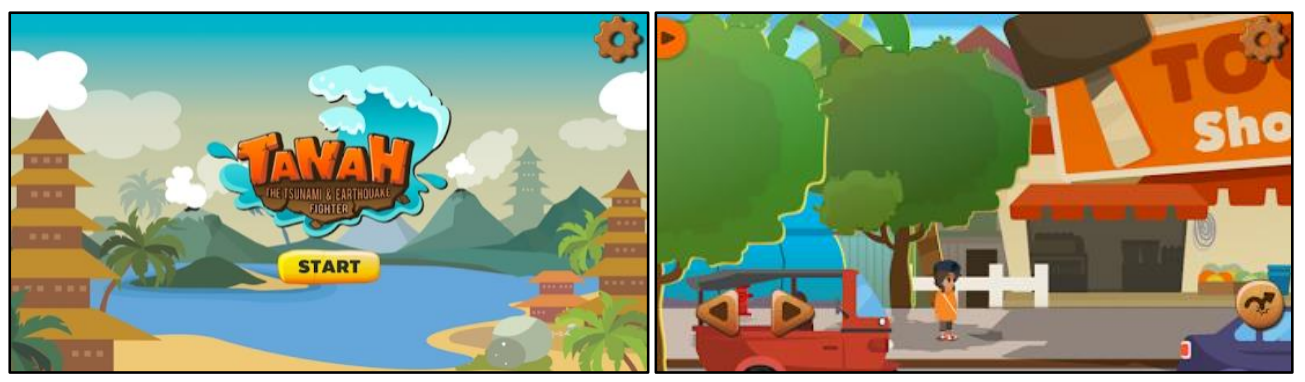

Figure 5. Screen captures from Tanah showing the start screen and the main character shopping for equipment.

\section{Effectiveness of serious games}

The second objective of this paper is to assess evidence for the effectiveness of the specific SGs for tsunami risk communication identified previously. This section provides a brief summary of evidence specifically related to the effectiveness of the four games, Disaster Master, Earth Girl 2, Stop Disasters and Tanah - Tsunami and Earthquake Fighter.

\subsection{Challenges of measuring the effectiveness of serious games}

While it is beyond the scope of this article to summarise the entire debate related to measuring the effectiveness of SGs, it is central to the argument for use of this approach for communication of risk. It is necessary to differentiate between 1) measuring the effectiveness of SGs compared to other methods of risk communication and;2) measuring the effectiveness of specific SGs at communicating tsunami risk. 
However, it is necessary to consider what "we", as educators, are trying to communicate to learners. In particular, in the case of tsunami evacuation there exists an important question related to assisting others versus focussing on self-reliance. This is referred to herein as evacuation philosophy.

The so called "Tendenko" philosophy suggests active self-determination and reliance in terms of evacuation decision-making and action, where evacuees are encouraged to focus on their timely evacuation without delaying for any reason, including to help others. It should be noted that this philosophy is multi-layered and born out of generations of experience living in the Tohoku region of Japan which is prone to large tsunami [19]. In cases where tsunami arrival time is short, such as the 2018 Sulawesi Earthquake, where an earthquake triggered a submarine landslide, "residents must quickly establish a link between strong ground shaking and the potential for a tsunami to arrive and start evacuation immediately by their own initiative" $[85$, p. 10$]$.

In contrast, an altruistic approach suggests that helping others is the priority, even if by delaying your own evacuation and thereby increasing your own risk. These differences in evacuation philosophy are reflected in the game reward mechanisms which could affect how learners make decisions during a potential hazard event. Kerlow [80], who was instrumental in the development of the game "Earth Girl", "decided to focus on the emotional experience of the player"... and "placed emotional impact above a purely rational understanding of the issues". He went on to remark that "it was appropriate, since the essence of the game is about saving people" $[80$, p. 2]. In the game, players are rewarded for saving villagers. Game philosophy is an important consideration because what games 'teach' should affect what learners do in response to a natural hazard event and could result in negative outcomes.

Effectiveness evaluations are frequently not used for disaster related SGs, [86] subsequently, there is a significant gap in the debate about the effectiveness of using SGs for risk communication. However, some examples are outlined, as they provide an indication of the discussion.

Bachvarova et al [87] investigated measuring effectiveness of SGs in corporate scenarios. They reviewed the Kirkpatrick Scale which has been widely used to evaluate corporate training. However, they noted that the Kirkpatrick scale [88] was designed for an approach to classroom instruction which was commonly used when the scale was developed in 1994, and that it should be reassessed for use in the development of metrics for evaluating SGs.

A meta-analysis which reviewed SGs in educational settings, specifically targeted games used for teaching traditional school subjects which included mathematics, geography and computer science subjects in a formal educational environment. Some of the games addressed less traditional topics, including bullying and firefighting. They concluded that "the evidence that serious games can be effective learning materials in their own right is quite strong" [89, p. 7]. They selected forty studies out of which twenty-nine showed positive results, seven studies showed neutral results and two were negative. Two of the studies were unclear. They also asserted that the game based approach "resulted in better learning motivation for learners in the experimental group". However, academic achievement was not significantly different between the experimental and the control groups.

In the context of flood risk management, an approach using Kolb's Learning Model was used. The game-based approach familiarised learners with the available responses and hazard terminology and showed high levels of learner interest. The approach produced better outcomes in terms of learner motivation, experience and engagement and more effective results in comparison to a textbook-based learning approach [90]. 
pag. 32

\subsection{Game design considerations}

Children naturally learn through play to make sense of the world around them. Digital games are a natural medium for most children and facilitate contextualisation of players learning experiences, support situated cognition and provide more motivating experiences than traditional education methods. Evidence suggests that SG can be effective learning tools if implemented well [31], [91], [92]. However, the multidisciplinary process and lack of methods for infusing pedagogy in a deep and effective way represent a complex challenge [91].

Choices made at the game design stage are a critical consideration which are likely to affect the effectiveness of an SG, subsequently game designers look for methods to inform design choices. A variety of development approaches and pedagogical models are available [93], however, it is generally accepted that game characteristics and particularly game mechanics can significantly affect learning outcomes [91], [92], [94].

Following the Game Object Model [95] and having recognised the challenges of designing SG which facilitate learning but also maintain player engagement Arnab et al. [96] introduced the concept of serious game mechanics as a learning goal implemented as a mechanical element of gameplay whose purpose is to support the play element of the game. The learning mechanics - game mechanics (LM-GM) model is predicated on the assumption that high level pedagogical objectives can be interpreted and realised through low level game mechanics [96].

The LM-GM model which provides an SG analysis framework informs both designers and teachers to evaluate the effectiveness of an SG and how it could be used in an educational setting. They concluded; 1) some game mechanics used in entertainment games were suitable for use in SGs; 2) demonstrated the LM-GM could be used to support the evaluation of SG; 3) stressed the importance of assessment of SG and in particular noted that stealth embedded assessment is helpful to maintain the players flow experience uninterrupted.

The LM-GM model has been examined in relation to the principal learning theories and found that certain game mechanics are associated with certain learning mechanics [97]. This model provides a useful tool for game designers to select game mechanics based on the desired learning outcomes.

However, moving beyond medium focused proof of concept arguments to game characteristics that affect cognitive consequences is recommended [92]. As such it is necessary to focus on design decisions which optimise learning effectiveness, but game design as a second order design problem demonstrates how complex it is to predict the effect of design decisions on player experience [93].

Games are conceived and developed in a design context but deployed in an educational context usually by teams of designers and educators often with different perspectives [98]. There are significant challenges associated with deploying SGs in the classroom [99], [100] including support provision for educators, inadequate IT infrastructure and the ability for educators to organise a number of complex organizational resources [99]. The consideration of both context and organisational challenges at the design stage will influence the effectiveness of the game.

In this study, the engagement characteristics of the selected games were considered from the educator /learner perspective, as teachers who do not engage with an SG for any reason will simply opt for an alternative activity. These informal engagement characteristics for the selected games are summarised in table 2 in the appendix.

Increasingly the use of design patterns is being employed in SG design and development. By facilitating re-use and providing a method for more formal documentation, design patterns should be considered as part of the design considerations [101], [93]. 
The diagram below outlines the contributions from stakeholder groups as inputs to the SG requirements development process. Effectiveness of SGs is likely to be influenced by stakeholder involvement.

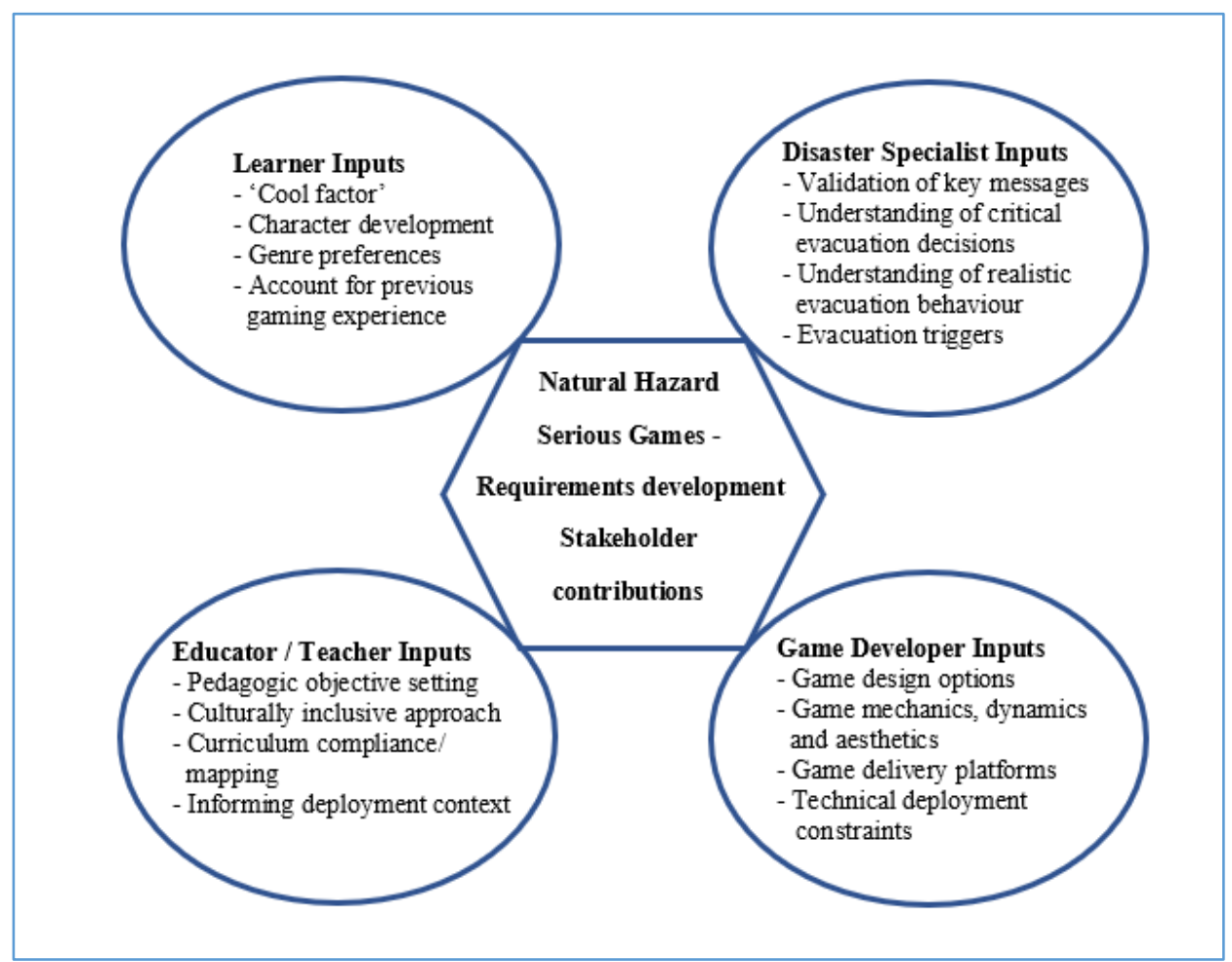

Figure 6. Stakeholder contributions to requirements development process.

While some evidence exists for the effectiveness of SGs as effective risk communication tools, this study intends to assess evidence that supports the following specific research question. Are SGs more effective than traditional teaching methods at communicating tsunami risk to secondary school aged children?

In order to address this question, the research will initially a) review the availability of tsunami SGs; and b) examine evidence for their effectiveness.

\subsection{Effectiveness of the selected tsunami games}

\subsubsection{Disaster Master effectiveness}

Disaster Master is the simplest application to use as it is web based, accessible on PC, Tablet and mobile phones and requires very little preparation for educators to setup. The application covers some key learning points related to natural warning sign of tsunami, decision-making and evacuation. No evidence of experimental testing was found in the literature but Findlay [43] summarised the learning points (referred to as key messages) which were present in the game in the form of a knowledge matrix. The application could be used in conjunction with other resources as the basis for discussion and debrief activities, as it provides a good general overview of a number of natural hazards.

\subsubsection{Stop Disasters effectiveness}

Stop Disasters is a game focused on planning for hazards from a community perspective. It is focused on investing in the built infrastructure of the community, as a way of preserving the infrastructure during a hazard event, rather than equipping the community with evacuation decision-making skills. As such it takes the community, rather than the personal/individual, view of a disaster event, and may be suitable for older learners who are already familiar with evacuation principles. 
pag. 34

Felicio et al. [102] assessed the game with randomly selected school children aged 1013 in a Rio de Janeiro high school. They conducted two scenarios. In the first, 185 students of different grades played the game using one of the five hazard scenarios in the game. The second scenario, involved 23 students and was an experiment focused on the flood scenario because it is a prevalent risk in Brazil. Students who undertook the first scenario were excluded from the second scenario. Both scenarios used a pre-test and post-test questionnaire to collect data on the students' game experience, elements of the game that could be improved and understanding of natural disasters.

They noted that participants became excited about the game, chanting the countdown together and noting the rank and the scores. They concluded that children who had played the game significantly changed their perception of the risks suggesting that the use of the games raised their risk awareness [102]. This suggests that the game was effective in this case.

\subsubsection{Earth Girl and Earth Girl 2 effectiveness}

No formal evidence related to the effectiveness of Earth Girl or Earth Girl 2 was found during this research.

\subsubsection{Tanah - Tsunami and Earthquake Fighter effectiveness}

Tanah is a game that addresses the issue of preparation and evacuation in an earthquake and tsunami scenario. It is an Android only game, developed by Opendream.

There is limited experimental work related to the effectiveness of this game, however, research ${ }^{2}$ using a pre-experimental design and a one group pretest-posttest design with simple random sampling technique to assess it's effectiveness was conducted. The subjects were school children, with most respondents 10 -year-old boys who were taught using the Tanah game.

The study used a Wilcoxon test, where $\mathrm{p}=0.000<0.05$ and concluded that there was a significant effect concluding, "providing education based on the android game land of the tsunami and earthquake conquerors on students preparedness to face disasters" [103, p. 60]. As such, there is some evidence that the Tanah - Tsunami and Earthquake Fighter game is effective in communicating tsunami risk to children. Further research concluded a significant difference between experiment group and control group for use of an androidbased earthquake game, but did not specify which game had been used in the study [104].

${ }^{2}$ This study was translated from Indonesian to English using translation software. 


\subsubsection{Mapping key messages to the tsunami games.}

The research focused on the communication of key messages through the games identified by this literature review. The table below presents a mapping between 7 key messages related to tsunami natural warnings from [11] and their representation in the games reviewed in this article. It is clear that none of the games address all 7 of the key messages.

Table 1. Mapping of key messages to tsunami games

\begin{tabular}{|c|c|c|c|c|c|}
\hline Game & $\begin{array}{l}\text { Disaster } \\
\text { Master }\end{array}$ & $\begin{array}{c}\text { Stop } \\
\text { Disasters }\end{array}$ & Earth Girl & Earth Girl 2 & $\begin{array}{l}\text { Tanah: The } \\
\text { Tsunami } \\
\text { and } \\
\text { Earthquake } \\
\text { Fighter }\end{array}$ \\
\hline \multicolumn{6}{|c|}{ Natural Warning Signs of Tsunami } \\
\hline $\begin{array}{l}\text { Ground } \\
\text { shaking. }\end{array}$ & $\begin{array}{l}\text { No. Shaking is not a } \\
\text { pre-cursor to } \\
\text { tsunami in DM. } \\
\text { Earthquake scenario } \\
\text { happens after the } \\
\text { tsunami scenario, in } \\
\text { a different location. }\end{array}$ & No. & No. & $\begin{array}{l}\text { Yes. Based on the } \\
\text { video } \\
\text { demonstration } \\
\text { [82]. }\end{array}$ & $\begin{array}{l}\text { Ground shaking } \\
\text { occurs but is not } \\
\text { mentioned as a } \\
\text { natural warning } \\
\text { sign. Villagers } \\
\text { in the game rely } \\
\text { on a warning } \\
\text { system. }\end{array}$ \\
\hline $\begin{array}{l}\text { Rise / fall of } \\
\text { coastal } \\
\text { waters. }\end{array}$ & Yes. & No. & No. & No. & No. \\
\hline $\begin{array}{l}\text { Coastal } \\
\text { Water noise. }\end{array}$ & No. & $\begin{array}{l}\text { Yes. Players } \\
\text { hear the sound } \\
\text { of the } \\
\text { approaching } \\
\text { wave. }\end{array}$ & $\begin{array}{l}\text { No. None other } \\
\text { than general sea } \\
\text { noise. }\end{array}$ & No. & No. \\
\hline \multicolumn{6}{|c|}{ Evacuation Key Messages } \\
\hline $\begin{array}{l}\text { Do not delay } \\
\text { your } \\
\text { evacuation. }\end{array}$ & $\begin{array}{l}\text { Yes. Character } \\
\text { continues to run up } \\
\text { the hill as she warns } \\
\text { the man watching } \\
\text { the wave. }\end{array}$ & $\begin{array}{l}\text { No. Does not } \\
\text { address } \\
\text { evacuation. }\end{array}$ & $\begin{array}{l}\text { No. Earth Girl } \\
\text { spends time } \\
\text { pushing villagers } \\
\text { away from the } \\
\text { beach. }\end{array}$ & $\begin{array}{l}\text { Not explicitly } \\
\text { mentioned } \\
\text { although villagers } \\
\text { do not delay } \\
\text { evacuation to help } \\
\text { others. }\end{array}$ & $\begin{array}{l}\text { No. Tanah } \\
\text { delays her } \\
\text { evacuation to } \\
\text { give a tsunami } \\
\text { warning. }\end{array}$ \\
\hline $\begin{array}{l}\text { Tsunamis } \\
\text { come in } \\
\text { waves \& can } \\
\text { last for } \\
\text { hours. }\end{array}$ & Yes & $\begin{array}{l}\text { No. There is a } \\
\text { single wave in } \\
\text { the tsunami } \\
\text { scenario. }\end{array}$ & $\begin{array}{l}\text { Yes. Instructions } \\
\text { indicate a second } \\
\text { wave will arrive. }\end{array}$ & No. & No. \\
\hline $\begin{array}{l}\text { Vertical } \\
\text { Evacuation. }\end{array}$ & $\begin{array}{l}\text { No. Characters run } \\
\text { uphill, but do not } \\
\text { vertically evacuate } \\
\text { in buildings. }\end{array}$ & $\begin{array}{l}\text { No. Does not } \\
\text { address } \\
\text { evacuation. }\end{array}$ & No & $\begin{array}{l}\text { Not explicitly } \\
\text { mentioned. Some } \\
\text { villagers go to } \\
\text { elevated } \\
\text { evacuation centre. }\end{array}$ & Yes. \\
\hline $\begin{array}{l}\text { Post tsunami } \\
\text { caution. }\end{array}$ & $\begin{array}{l}\text { Yes. Characters } \\
\text { exercise caution } \\
\text { related to building } \\
\text { re-entry. }\end{array}$ & $\begin{array}{l}\text { No. A report on } \\
\text { damage is } \\
\text { presented to } \\
\text { players. }\end{array}$ & $\begin{array}{l}\text { Mentions second } \\
\text { wave in the } \\
\text { instructions but } \\
\text { not as part of } \\
\text { gameplay. }\end{array}$ & No. & $\begin{array}{l}\text { Caution related } \\
\text { to broken glass. } \\
\text { Tanah searches } \\
\text { for a first aid kit } \\
\text { and tends to and } \\
\text { injured person. }\end{array}$ \\
\hline
\end{tabular}

It is interesting to reflect on why the key messages remain un-addressed and what this may indicate. However, without thorough knowledge of the development process for each game, it remains speculative. Key messages related to tsunami natural warning signs may not have been considered significant enough to be included in the game, especially as the game 
pag. 36

scenarios tended to include a warning system. It is also possible they were overlooked during requirements elicitation and development process, or they were considered low priority and were 'traded out' in favour of higher priority requirements. However the key message 'Drop, Cover, Hold' related to earthquakes [105] was clearly communicated in the 'Tanah' game.

\section{Conclusion and recommendations}

The objective of the research presented in this paper was twofold: a) To find evidence of deployable tsunami SGs that include evacuation decision-making; and b) Assess the literature for the effectiveness of these games and their inclusion of actionable key messages.

The main findings are that: Regarding a), the very few existing tsunami SGs do not equip learners with skills to make informed evacuation decisions and that they could (and should) be improved. Indeed, design options (mainly using game mechanics) do exist that could help to improve tsunami SGs to deliver learning objectives and outputs that go beyond a general improved awareness and, instead, enhance knowledge on actionable key messages. This approach could be generalised to other natural hazard risk communication, such as floods, earthquakes and wildfires. Regarding b), the formal assessment of the effectiveness of SGs for risk communication (and tsunami risk communication, in particular) is very limited. It is also evident that measuring the effectiveness between two similar games is very challenging because games are not standardised - objectives or approaches, as well as characteristics such as game narrative, game mechanics, evacuation philosophy and graphics, vary between games. More specifically, our review of existing SGs revealed a number of issues that could contribute to future research focused on these improvements. This has allowed us to make a number of recommendations.

Because of the limited number of SGs, it follows that educators have a very limited choice when choosing to adopt a SG based approach to teaching 'how to recognise the signs of a tsunami and what to do in this situation'. Nevertheless, given the familiarity of most children with digital games, one can conclude that exploiting SG technology to capture the high levels of learner motivation would be an appropriate way to carry out 'experiential learning' in the classroom. To do so, the full potential of SGs needs to be exploited more fully in order to address specific learning outcomes more completely.

Inclusion of stakeholder group information will improve game effectiveness. Disaster Specialists can inform the inclusion of action oriented key messages which would improve risk communication and also support the development of coping appraisals for learners, who are expected to make appropriate decisions in hazard situations.

From the education establishment; games need to be traceable to learning objectives if they are to be accepted by the educational establishment. This would help educators to select a game in line with their teaching program, or potentially use the game as common ground between subjects to facilitate cross curricular teaching. Future developments of natural hazard SGs should include credible, current, action-oriented messages from the disaster research community to be include in the game. Games should also address specific, identifiable, approved educational objectives. These should be traceable to one or many curriculum goals, potentially across different subject areas.

Equitable inclusion of stakeholder views during SG development is likely to increase the effectiveness of the game. Input from all stakeholder groups is vitally important to the effectiveness of the game. This includes experienced educators, learner representatives, disaster specialists and game developers. Stakeholders should recognise the sophisticated nature and understanding of children's gameplay experience and preferences. Games will be more engaging with certain characteristics which players may find "cool" (although some educators may not), such as the incredible destructive effects of a tsunami. Best practice participatory development and requirements management will ensure stakeholder 
contributions are managed and is likely to improve the quality of the final product and the effectiveness of risk communication outcomes. Requirements should be attributed to stakeholders, prioritised, traceable and should be validated and verified with stakeholders through an iterative process, such as prototype development and feedback.

Consideration of the deployment context of the game, (educational, technical and cultural) is critical to the success and effectiveness of learning outcomes. It is recommended that all stakeholders should understand the deployment context of the proposed game during the design stage. These considerations must include as a minimum, educators IT experience, subject matter knowledge, cultural and organisation contexts, learner developmental stage and IT infrastructure constraints. Even in industrialized countries, some schools lack computing facilities and support and educators are sufficiently time constrained that anything beyond minimal setup is reason enough to revert to traditional teaching approaches. Risk communication effectiveness will be enhanced by the provision of support materials and facilitator training which ideally would be delivered through concise video or online tutorials, thereby reducing the need for lengthy training workshops.

Game Development Models could aim to include critical information considerations. Models that aim to derive game mechanics from high level pedagogical objectives are at risk of addressing general concepts and not identifying critical information which would allow learners to make actionable decisions during a hazard event. As such, future development of such models could aim to include an information layer which would facilitate traceability to critical information such as curriculum goals (in education authority documents) as well as actionable advice from disaster research organisations.

Increasingly digital technologies play a significant role in education and can support issues that are high on the educational agenda for the $21^{\text {st }}$ century. These include an increasing focus on environmental management, sustainable development, disaster preparedness and risk management. In line with these potential reforms to educational methods and practice, more varied approaches can help target a wider learner audience including adults and individuals with limited access to formal educational systems. However, this review concurs with [106] that pedagogical implications of SGs in the classroom need further investigation. Finally, where no single method of risk communication or body of best practice will address all communication scenarios [9], it is reasonable to conclude that SGs have an important part to play in an increasingly digital learning experience.

\section{Declaration}

I can confirm that there are no known conflicts of interest associated with this publication and there has been no financial support for this work that could have influenced its outcome. 
pag. 38

\section{Appendix - Literature search terms and game engagement characteristics}

Table 1 provides a summary of search term details used and the number of documents retrieved.

Table 2. Details of search terms used and documents retrieved

\begin{tabular}{|c|c|c|c|c|c|}
\hline $\begin{array}{l}\text { With all } \\
\text { the words }\end{array}$ & $\begin{array}{l}\text { With the exact } \\
\text { phrase }\end{array}$ & Allintext & Date range & Results & $\begin{array}{l}\text { Reason for } \\
\text { refined search }\end{array}$ \\
\hline games risk & serious games & Yes & $2004 / 2020$ & 18,800 & Irrelevant titles \\
\hline games risk & $\begin{array}{c}\text { "serious } \\
\text { games"'risk } \\
\text { management" }\end{array}$ & Yes & $2004 / 2020$ & 2430 & Irrelevant titles \\
\hline $\begin{array}{c}\text { games risk } \\
\text { tsunami }\end{array}$ & serious games & Yes & $2004 / 2020$ & 522 & Irrelevant titles \\
\hline games risk & $\begin{array}{c}\text { "serious } \\
\text { games""risk } \\
\text { communication" }\end{array}$ & Yes & $2004 / 2020$ & 510 & Unrelated titles \\
\hline $\begin{array}{c}\text { games risk } \\
\text { tsunami }\end{array}$ & $\begin{array}{c}\text { "serious } \\
\text { games""risk } \\
\text { management" }\end{array}$ & Yes & $2004 / 2020$ & 143 & $\begin{array}{l}\text { Refined search / } \\
\text { reviewed }\end{array}$ \\
\hline $\begin{array}{c}\text { games risk } \\
\text { tsunami }\end{array}$ & $\begin{array}{c}\text { "serious } \\
\text { games""risk } \\
\text { communication" }\end{array}$ & Yes & $2004 / 2020$ & 40 & Reviewed \\
\hline $\begin{array}{l}\text { games risk } \\
\text { tsunami } \\
\text { children }\end{array}$ & $\begin{array}{c}\text { "serious } \\
\text { games""risk } \\
\text { communication" }\end{array}$ & Yes & $2004 / 2020$ & 25 & Reviewed \\
\hline
\end{tabular}


The table below summarises aspects of the games which may affect learner's and educator's engagement. The groups are adapted from [107]. Many children are familiar with highly sophisticated commercially developed video games and as such can have high expectations from video games. From the learner's perspective these features may help them to feel that the game is "cool," and therefore engaging, rather than unappealing. Educators are more likely to use an SG if it provides accurate information, is user friendly and requires minimal setup overheads.

Table 3. Summary of game engagement characteristics

\begin{tabular}{|c|c|c|c|c|c|c|}
\hline Game & $\begin{array}{c}\text { Disaster } \\
\text { Master }\end{array}$ & $\begin{array}{c}\text { Stop } \\
\text { Disasters }\end{array}$ & Earth Girl & $\begin{array}{c}\text { Earth Girl } \\
2\end{array}$ & Tanah & Group \\
\hline Graphics Quality & 2.5 & 3.5 & 2.5 & 2.5 & 3.5 & Presentation \\
\hline $2 \mathrm{D} / 3 \mathrm{D}$ & $2 \mathrm{D}$ & $3 \mathrm{D}$ & $2 \mathrm{D}$ & $2 \mathrm{D}$ & $2 \mathrm{D}$ & Presentation \\
\hline Active Movement & No & Yes & Yes & Yes & Yes & Presentation \\
\hline Sound / No Sound & No sound & Sound & Sound & Sound & Sound & Presentation \\
\hline $\begin{array}{l}\text { Accurate Information / } \\
\text { Advice }\end{array}$ & Yes & $\begin{array}{c}\text { No } \\
\text { evacuation } \\
\text { messages } \\
\text { provided. }\end{array}$ & $\begin{array}{l}\text { Not all. } \\
\text { Stun } \\
\text { tsunami } \\
\text { with force } \\
\text { field. }\end{array}$ & Unverified & $\begin{array}{c}\text { Natural } \\
\text { warning } \\
\text { signs not } \\
\text { fully } \\
\text { covered. }\end{array}$ & Education \\
\hline Time Constrained & No & Yes & Yes & Yes & No & Narrative \\
\hline Repetitive Narrative & Yes & Yes & Yes & Unverified & Yes & Narrative \\
\hline Character Focused & Yes & No & Yes & $\begin{array}{l}\text { Yes, but } \\
\text { less than } \\
\text { Earth Girl. }\end{array}$ & Yes & Narrative \\
\hline $\begin{array}{l}\text { Evacuation Philosophy } \\
\text { (Self-reliant / help } \\
\text { others) }\end{array}$ & $\begin{array}{l}\text { Self-reliant } \\
\& \text { helping } \\
\text { but without } \\
\text { self-delay }\end{array}$ & $\begin{array}{c}\text { No } \\
\text { evacuation } \\
\text { messages } \\
\text { provided. }\end{array}$ & $\begin{array}{c}\text { Delay own } \\
\text { evacuation } \\
\text { to help } \\
\text { others }\end{array}$ & Unverified & $\begin{array}{c}\text { Delay own } \\
\text { evacuation } \\
\text { to help } \\
\text { others. }\end{array}$ & Education \\
\hline Language Support & $\begin{array}{l}\text { English \& } \\
\text { Spanish }\end{array}$ & $\begin{array}{l}\text { English, } \\
\text { Spanish, } \\
\text { French, } \\
\text { Chinese, } \\
\text { Russian }\end{array}$ & $\begin{array}{c}\text { Chinese, } \\
\text { English, } \\
\text { French, } \\
\text { Indonesian, } \\
\text { Japanese }\end{array}$ & $\begin{array}{c}\text { English } \\
\text { Indonesian, } \\
\text { Thai,Tamil } \\
\text { and French }\end{array}$ & $\begin{array}{c}\text { English, } \\
\text { Bahasa } \\
\text { Indonesian, } \\
\text { Thai }\end{array}$ & Education \\
\hline $\begin{array}{c}\text { Educator Support } \\
\text { Material }\end{array}$ & Yes & Not found & Not found & Not found & Not found & Education \\
\hline Hardware Platform & $\begin{array}{c}\text { PC } \\
\text { Browser } \\
\text { Based }\end{array}$ & $\begin{array}{l}\text { PC / MAC } \\
\text { Tablet or } \\
\text { phone }\end{array}$ & $\begin{array}{l}\text { Flash } \\
\text { enabled } \\
\text { browser }\end{array}$ & Tablet & Android & Technical \\
\hline
\end{tabular}

1 - Graphics quality - This may affect whether children find the game "cool" or "boring". 2 - Presentation of environment in 2D or 3D.

3 - Are characters in the environment dynamic or are they presented as static images?

4 - The game has sound / no sound.

5 - Is the information presented in the game accurate/possible?

6 - Does the game involve a time constraint? (For example, a countdown timer), this is a central concept in evacuation decision-making.

7 - The game follows the same story/scenario each time it is played. 
pag. 40

8 - The game is character focused or community focused. (Younger children may be more empathetic towards a character focused activity.) Discussion and de-brief activities may be facilitated by strong characters and narrative.

9 - The evacuation philosophy employed in the game - "Tendenko" (Self Reliant) or altruistic / community (helping others but risking self-delay).

10 - Languages supported in the game.

11 - Educator support material availability.

12 - The hardware platform which the game operates on.

\section{References}

[1] K. R. Ronan, E. Alisic, B. Towers, V. A. Johnson, and D. M. Johnston, "Disaster Preparedness for Children and Families: a Critical Review," Curr. Psychiatry Rep., vol. 17, no. 7, pp. 1-9, 2015, doi: 10.1007/s11920-015-0589-6.

[2] S. Rajib, T. Yukiko, R. G. Qi, and S. Koichi, "Chapter 1 Disaster Education: An Introduction," in Disaster Education, vol. 7, R. Shaw, K. Shiwaku, and Y. Takeuchi, Eds. Emerald Group Publishing Limited, 2011, pp. 1-22. https://doi.org/10.1108/S20407262(2011)0000007007.

[3] C. E. Gregg et al., "Natural warning signs of tsunamis: Human sensory experience and response to the 2004 Great Sumatra earthquake and tsunami in Thailand," Earthq. Spectra, vol. 22, no. SUPPL. 3, 2006, doi: 10.1193/1.2206791.

[4] S. Chatterjee, "Children's Coping, Adaptation and Resilience through Play in Situations of Crisis," Child. Youth Environ., vol. 28, no. 2, pp. 119-145, 2018.

doi: 10.7721/chilyoutenvi.28.2.0119.

[5] R. I. Ogie, J. C. Rho, and R. J. Clarke, "Artificial Intelligence in Disaster Risk Communication: A Systematic Literature Review," 2018 5th Int. Conf. Inf. Commun. Technol. Disaster Manag. ICT-DM 2018, pp. 1-8, 2019, doi: 10.1109/ICTDM.2018.8636380.

[6] E. E. H. Doyle, D. M. Johnston, R. Smith, and D. Paton, "Communicating model uncertainty for natural hazards: A qualitative systematic thematic review," Int. J. Disaster Risk Reduct., vol. 33, no. November 2018, pp. 449-476, 2019, doi: 10.1016/j.ijdrr.2018.10.023.

[7] M. Tsai, Y. Chang, S. Shiau, and S. Wang, "Exploring the effects of a serious game-based learning package for disaster prevention education: The case of Battle of Flooding Protection," Int. J. Disaster Risk Reduct., vol. 43, 2020, doi: 10.1016/j.ijdrr.2019.101393.

[8] A. V. Gampell, J. Gaillard, and M. Parsons, "On the use of participatory methodologies for video game research: Exploring disaster risk reduction in video games," Methodol. Innov., vol. 12, no. 3, p. 205979911988427 , 2019, doi: 10.1177/2059799119884277.

[9] D. Demeritt, "Models of best practice in flood risk communication and management," no. December, 2014, doi: 10.1080/17477891.2014.924897.

[10] D. Mileti and J. Derouen, "The Role of Searching in Shaping Reactions to Earthquake Risk Information The Role of Searching in Shaping Reactions to Earthquake Risk Information Author ( s ): Dennis S . Mileti and Joanne Derouen Darlington Published by: Oxford University Press on beh," Soc. Probl., vol. 44, no. 1, February 1997, pp. 89-103, 1997, doi: https://doi.org/10.2307/3096875. 
[11] International Federation of the Red Cross and Red Crescent Societies; Save the Children International, "Public awareness and public education for disaster risk reduction: Actionoriented key messages for households and schools - Second edition - Updated and revised," 2018. Available: https://media.ifrc.org/ifrc/wp-content/uploads/sites/5/2018/11/PAPE-AWWEB-min.pdf.

[12] UNESCO International Tsunami Information Center, "International Tsunami Information Center Home Page." http://itic.ioc-unesco.org/index.php (accessed Sep. 15, 2020).

[13] T. Mikami, T. Shibayama, M. Esteban, and R. Aránguiz, "Comparative Analysis of Triggers for Evacuation during Recent Tsunami Events," Nat. Hazards Rev., vol. 21, no. 3, p. 04020022, 2020, doi: 10.1061/(asce)nh.1527-6996.0000386.

[14] M. Petal, "Disaster Risk Reduction Education:Material Development, Organization, and Evaluation," Reg. Dev. Dialogue J., vol. 28, no. 2, pp. 1-25, 2008, [Online]. Available: https://www.researchgate.net/publication/277821824_Disaster_Risk_Reduction_Education _Material_Development_Organization_Evaluation.

[15] M. M. Barry, C. Oroviogoicoechea, and F. Guillen-grima, "A literature review on effective risk communication for the prevention and control of communicable diseases in Europe Insights into health communication," no. January, 2013, doi: 10.2900/64747.

[16] J. K. Wardman, "The Constitution of Risk Communication in Advanced Liberal Societies," Risk Anal., vol. 28, no. 6, pp. 1619-37, 2008, doi: 10.1111/j.1539-6924.2008.01108.x.

[17] M. J. Simis, H. Madden, M. A. Cacciatore, and S. K. Yeo, "The lure of rationality: Why does the deficit model persist in science communication?," Public Underst. Sci., vol. 25, no. 4, pp. 400-414, 2016, doi: 10.1177/0963662516629749.

[18] W. F. Bodmer, "The Public Understanding of Science," Rep. a R. Soc. ad hoc Gr. endorsed by Counc. R. Soc., 1985. Available:

https://royalsociety.org/ /media/royal_society_content/policy/publications/1985/10700.pdf

[19] K. Yamori, Disaster Risk Communication. Singapore: Springer Singapore, 2020. https://doi.org/10.1007/978-981-13-2318-8.

[20] E. Rollason, L. J. Bracken, R. J. Hardy, and A. R. G. Large, "Rethinking flood risk communication," Nat. Hazards, vol. 92, no. 3, pp. 1665-1686, 2018, doi: 10.1007/s11069018-3273-4.

[21] R. W. Rogers, "A Protection Motivation Theory of Fear Appeals and Attitude Change1," J. Psychol., vol. 91, no. 1, pp. 93-114, 1975, doi: 10.1080/00223980.1975.9915803.

[22] National Research Council, Improving Risk Communication. Washington, DC: The National Academies Press, 1989. https://doi.org/10.17226/1189.

[23] K. Kraiger, J. K. Ford, and E. Salas, "Application of Cognitive, Skill-Based, and Affective Theories of Learning Outcomes to New Methods of Training Evaluation," J. Appl. Psychol., vol. 78, no. 2, pp. 311-328, 1993, doi: 10.1037/0021-9010.78.2.311.

[24] G. M. Bodner, "Constructivism: A Theory of Knowledge," J. Chem. Educ., vol. 63, pp. 873878, 1986, doi: http://dx.doi.org/10.1021/ed063p873.

[25] S. Olusegun, "Constructivism Learning Theory: A Paradigm for Teaching and Learning," vol. 5, no. 6, pp. 66-70, 2015, doi: 10.9790/7388-05616670.

[26] J. Becker, D. M. Johnston, J. S. Becker, D. Paton, M. Johnston, and K. R. Ronan, “A model of household preparedness for earthquakes: How individuals make meaning of earthquake information and how this influences preparedness," Nat. Hazards, no. May 2016, 2012, doi: 10.1007/s11069-012-0238-x. 
[27] T. Anastasiadis, G. Lampropoulos, and K. Siakas, "Digital Game-based Learning and Serious Games in Education,” Int. J. Adv. Sci. Res. Eng., vol. 4, no. 12, pp. 139-144, 2018, doi: 10.31695/ijasre.2018.33016.

[28] M. D. Duerden and P. A. Witt, "The impact of direct and indirect experiences on the development of environmental knowledge, attitudes, and behavior," J. Environ. Psychol., vol. 30, no. 4, pp. 379-392, 2010, doi: 10.1016/j.jenvp.2010.03.007.

[29] M. Prensky, "The Motivation of Gameplay or, the REAL 21st century learning revolution," Horiz., vol. 10, no. No. 1, pp. 5-11, 2002, doi: 10.1108/10748120210431349.

[30] D. Crookall, "Serious games, debriefing, and simulation/gaming as a discipline," Simul. Gaming, vol. 41, no. 6, pp. 898-920, 2010, doi: 10.1177/1046878110390784.

[31] F. Bellotti, B. Kapralos, K. Lee, P. Moreno-Ger, and R. Berta, "Assessment in and of serious games: An overview," Adv. Human-Computer Interact., vol. 2013, 2013, doi: $10.1155 / 2013 / 136864$.

[32] T. Mitchell, T. Tanner, and K. Haynes, "Children as agents of change for Disaster Risk Reduction : Lessons from El Salvador and the Philippines .," Brighton, 1, 2009. [Online]. Available: https://www.researchgate.net/publication/228376320_Children_as_Agents_of_Change_for _Disaster_Risk_Reduction_Lessons_from_El_Salvador_and_the_Philippines.

[33] C. Kousky, "Impacts of Natural Disasters on Children," Futur. Child., vol. 26, no. 1, pp. p73-92, 2016, doi: http://dx.doi.org/10.1353/foc.2016.0004.

[34] A. Amri et al., "Children' s Geographies Bridging the divide between studies on disaster risk reduction education and child-centred disaster risk reduction : a critical review," Child. Geogr., vol. 16, no. 3, pp. 239-251, 2018, doi: 10.1080/14733285.2017.1358448.

[35] L. G. H. Midtbust, A. Dyregrov, and H. W. Djup, "Communicating with children and adolescents about the risk of natural disasters," Eur. J. Psychotraumatol., vol. 9, no. sup2, 2018, doi: 10.1080/20008198.2018.1429771.

[36] D. Ball and G. Mcdiarmid, "The Subject Matter Preparation of Teachers.," in Handbook for Research on Teacher Education, W. R. Houston, Ed. New York: New York: Macmillan., 1989.

https://www.researchgate.net/publication/234587984_The_Subject_Matter_Preparation_of _Teachers_Issue_Paper_89-4

[37] B. Pfefferbaum, R. L. Pfefferbaum, and R. L. Van Horn, "Involving children in disaster risk reduction: the importance of participation," Eur. J. Psychotraumatol., vol. 9, no. sup2, 2018, doi: 10.1080/20008198.2018.1425577.

[38] R. Hasegawa, “Disaster Evacuation from Japan's 2011 Tsunami Disaster and the Fukushima Nuclear Accident," IDDRI, no. May, pp. 1-54, 2013, [Online]. Available: https://orbi.uliege.be/bitstream/2268/195804/1/STUDY0513_RH_DEVAST report-1.pdf.

[39] C. C. Abt, Serious Games. Lanham, MD USA: Viking Press, 1970. https://www.jstor.org/stable/4531446?seq=1.

[40] B. Sawyer, "Serious games: Improving public policy through game-based learning and simulation," 2002. Available:

https://www.researchgate.net/publication/243771574_Serious_games_Improving_public_p olicy_through_game-based_learning_and_simulation.

[41] L. Michaud and J. Alvarez, Serious Games: Advergaming, edugaming, training... Montpellier, France.: IDATE, 2008.

https://www.researchgate.net/publication/286354308_Serious_Games_Advergaming_edug aming_training. 
[42] D. Michael and S. Chen, Serious Games: Games That Educate, Train, and Inform. Course Technology PTR, 2006.

https://www.researchgate.net/publication/234812017_Serious_Games_Games_That_Educa te_Train_and_Inform.

[43] B. Findlay, "Digital Games in Disaster Preparedness Education," University of Auckland, 2017. https://doi.org/10.13140/RG.2.2.24698.03527.

[44] M. Lampe, S. Hinske, C. Magerkurth, and C. Röcker, "Classifying Pervasive Games: On Pervasive Computing and Mixed Reality," Concepts Technol. Pervasive Games A Read. Pervasive Gaming Res. Vol. 1, vol. 1, no. January, pp. 11-37, 2007, [Online]. Available: https://www.researchgate.net/publication/228626515_Classifying_pervasive_games_On_p ervasive_computing_and_mixed_reality.

[45] C. Haythornthwaite, R. Andrews, M. M. Kazmer, B. C. Bruce, R.-A. Montague, and C. Preston, "Theories and models of and for online learning," First Monday, vol. 12, no. 8 SEArticles, Aug. 2007, doi: 10.5210/fm.v12i8.1976.

[46] D. Djaouti, J. Alvarez, and J. Jessel, "Classifying Serious Games : the G / P / S model," in Handbook of Research on Improving Learning and Motivation through Educational Games: Multidisciplinary Approaches, P. Felicia, Ed. Hershey, PA: IGI Global, 2011, pp. 118-136. http://dx.doi.org/10.4018/978-1-60960-495-0.ch006

[47] G. Bente and J. Breuer, "Why so serious? On the Relation of Serious Games and Learning," Eludamos - J. Comput. Game Cult., vol. 4, no. 1, pp. 7-24, 2010, [Online]. Available: http://www.eludamos.org/index.php/eludamos/article/viewArticle/vol4no1-2.

[48] T. Susi, M. Johannesson, and P. Backlund, "Serious Games: An Overview," Skövde, Sweden, 2007.

Available: https://www.diva-portal.org/smash/get/diva2:2416/FULLTEXT01.pdf.

[49] S. Sampayo Vargas, J. R. Rankin, and P. F. Taylor, "Testing metaphorical educational FPS games," Int. J. Comput. Games Technol., vol. 2009, no. 1, pp. 3-8, 2009, doi: $10.1155 / 2009 / 456763$.

[50] R. Ratan and U. Ritterfeld, "Classifying serious games," in Serious games: Mechanisms and effects, U. Ritterfeld, M. Cody, and P. Vorderer, Eds. New York and London: Routledge, 2009, pp. 10-24.

https://www.researchgate.net/publication/262910877_Classifying_serious_games/citation/ download.

[51] D. Djaouti, J. Alvarez, and J.-P. Jessel, "Classifying Serious Games," in Handbook of Research on Improving Learning and Motivation through Educational Games: Multidisciplinary Approaches, January, Patrick Felicia, Ed. 2011, pp. 118-136. doi: 10.17083/ijsg.v1i1.11

[52] J. Hunt, J. M. Broom, W. H. Greene, J. W. Crawford, R. F. Martere, and J. R. Parish, "Multipurpose Arcade Combat Simulator (MACS)," 1987. [Online]. Available: https://www.researchgate.net/publication/235167850_Multipurpose_Arcade_Combat_Sim ulator_MACS.

[53] S. Yildirim, "Serious Game Design for Military Training," in Games: Design and Research Conference, 2014, no. January 2010, pp. 1-10, [Online]. Available: https://www.researchgate.net/publication/265707723_serious_game_design_for_military_t raining.

[54] S. Angelevski and D. Bogatinov, "Computer gaming technology for military trainingserious games," Int. Sci. DEFENCE, Secur. PEACE J., vol. 14, no. 26, pp. 73-85, 2014. Available: http://eprints.ugd.edu.mk/12694/.

[55] A. B. Samčović, "Serious Games in Military Applications," Mil. Tech. Cour., vol. 66, no. 3, pp. 597-613, 2018, doi: 10.5937/vojtehg66-16367. 
[56] A. Khorram-Manesh, J. Berlin, and E. Carlström, "Two Validated Ways of Improving the Ability of Decision-Making in Emergencies; Results from a Literature Review," Bull Emerg Trauma, vol. 4, no. 4, pp. 186-196, 2016.

Available: https://www.ncbi.nlm.nih.gov/pmc/articles/PMC5118570/pdf/bet-4-186.pdf.

[57] C. Zhang, T. Grandits, K. P. Härenstam, J. B. Hauge, and S. Meijer, "A systematic literature review of simulation models for non-technical skill training in healthcare logistics," Adv. Simul., vol. 3, no. 15, pp. 1-16, 2018, doi: doi.org/10.1186/s41077-018-0072-7.

[58] M. G. Metello, M. A. Casanova, and M. T. M. Carvalho, "Using serious game techniques to simulate emergency situations," in Proceedings of the Brazilian Symposium on GeoInformatics, 2008, no. April 2014, pp. 171-181. Available: https://www.researchgate.net/publication/220913332_Using_Serious_Game_Techniques_t o_Simulate_Emergency_Situations.

[59] G. Ra, J. Sung, H. Yu, and H. Min, "Analysis of Serious Games Based on Pedagogical Features and Proposal of Civil Defence Training Game," Int. J. Comput. Vis. Robot., vol. 6, no. 3, pp. 235-243, Jan. 2016, doi: 10.1504/IJCVR.2016.077354.

[60] A. Mossel, A.- Vienna, A. Peer, and J. Göllner, "Requirements Analysis on a Virtual Reality Training System for CBRN Crisis Preparedness," in ISSS-2015, 2017, pp. 1-20. Available: https://journals.isss.org/index.php/proceedings59th/article/view/2486.

[61] L. Sharp, "Stealth Learning: Unexpected Learning Opportunities Through Games," J. Instr. Res., vol. 1, pp. 42-48, 2012, doi: 10.9743/jir.2013.6.

[62] C. Garcia-Garcia, J. Luis Fernández-Robles, V. Larios-Rosillo, and H. Luga, "ALFIL: A crowd simulation serious game for massive evacuation training and awareness," Int. J. Game-Based Learn., vol. 2, no. 3, pp. 71-86, 2012, doi: 10.4018/ijgbl.2012070105.

[63] J. Ribeiro, J. E. Almeida, R. J. F. Rossetti, A. Coelho, and A. L. Coelho, "Using serious games to train evacuation behaviour," Iber. Conf. Inf. Syst. Technol. Cist., 2012, [Online]. Available:

https://www.researchgate.net/publication/261280150_Using_serious_games_to_train_evac uation_behaviour.

[64] Z. Feng, V. A. González, R. Amor, R. Lovreglio, and G. Cabrera-Guerrero, "Immersive virtual reality serious games for evacuation training and research: A systematic literature review," arXiv, no. July, 2018, [Online]. Available: https://www.researchgate.net/publication/325332898_Immersive_Virtual_Reality_Serious _Games_for_Evacuation_Training_and_Research_A_Systematic_Literature_Review.

[65] S. Smith and E. Ericson, "Using immersive game-based virtual reality to teach fire-safety skills to children," Virtual Real., vol. 13, no. 2, pp. 87-99, 2009, doi: 10.1007/s10055-0090113-6.

[66] A. Solinska-nowak et al., "An overview of serious games for disaster risk management Prospects and limitations for informing actions to arrest increasing risk," Int. J. Disaster Risk Reduct., vol. 31, no. August, pp. 1013-1029, 2018, doi: 10.1016/j.ijdrr.2018.09.001.

[67] P. Suarez and A. Patt, "Cognition, caution, and credibility: the risks of climate forecast application," Risk, Decis. Policy, vol. 9, no. 1, pp. 75-89, 2004, doi: 10.1080/14664530490429968.

[68] P. Suarez, "Using games to experience climate risk: Empowering Africa's decision-makers," 2013. Available:

http://www.climatecentre.org/downloads/files/Games/CDKNGamesReport.pdf.

[69] H. R. Parker et al., "Using a Game to Engage Stakeholders in Extreme Event Attribution Science," pp. 353-365, 2016, doi: 10.1007/s13753-016-0105-6.

[70] Pablo Suarez, "Games4sustainability:Climate Risk Management game - MASHLM," 2015. https://games4sustainability.org/2015/12/15/pablo-suarez-games/ (accessed Sep. 25, 2020). 
[71] A. Martín-Martín, E. Orduna-Malea, M. Thelwall, and E. Delgado López-Cózar, "Google Scholar, Web of Science, and Scopus: A systematic comparison of citations in 252 subject categories," J. Informetr., vol. 12, no. 4, pp. 1160-1177, 2018, doi: 10.1016/j.joi.2018.09.002.

[72] A.-W. Harzing, "Publish or Perish," Research in International Management, 2016. https://harzing.com/resources/publish-or-perish (accessed Sep. 20, 2020).

[73] B. Whaley, "Virtual Earthquakes and Real-World Survival in Japan's Disaster Report Video Game," J. Asian Stud., vol. 78, no. 1, pp. 95-114, 2019, doi: 10.1017/S0021911818002620.

[74] M. Hatayama, T. Kosaka, and A. H. Hernandeze, "Analysis on Tsunami Evacuation Options with Agent-based Simulation in Tourist Area," 2018 5th Int. Conf. Inf. Commun. Technol. Disaster Manag. ICT-DM 2018, 2019, doi: 10.1109/ICT-DM.2018.8636385.

[75] D. Jacoby, Y. Coady, E. Dahl, A. Wynden, and M. Richardson, "VR Tsunami!," in ACM SIGGRAPH 2019 Appy Hour, 2019, pp. 1-2, doi: 10.1145/3305365.3329728.

[76] Y. Kawai and Y. Kaizu, "Tsunami evacuation simulation system for disaster prevention plan," in Proceedings - 2019 International Conference on Cyberworlds, CW 2019, 2019, pp. 362-365, doi: 10.1109/CW.2019.00067.

[77] R. R. Alifia, F. Rahma, U. Hamida, A. P. Koesoema, Y. S.irawan, and S. Egawa, "Tsunami Fighters: Collaborative Multilingual Mobile Game for Earthquake and Tsunami Disaster Preparedness Education," in IEEE Region 10 Humanitarian Technology Conference, R10HTC, 2020, vol. December, doi: 10.1109/R10-HTC49770.2020.9357038.

[78] United Nations Regional Information Centre, "Stop Disasters!," 2015. https://unric.org/en/stop-disasters/ (accessed Oct. 25, 2020).

[79] Singapore Earth Observatory, "Earth Girl." http://earthgirlgame.com/game/tsunami/earth girl tsunami - english.swf (accessed Sep. 28, 2020).

[80] I. Kerlow, "Earth girl saves the day: A computer game prototype about earth hazards," Proc. - 2011 2nd Int. Conf. Cult. Comput. Cult. Comput. 2011, no. March, pp. 33-38, 2011, doi: 10.1109/Culture-Computing.2011.15.

[81] Singapore Earth Observatory, "Earth Girl Tsunami." https://earthgirl2.com/earth-girltsunami/ (accessed Sep. 28, 2020).

[82] Art-Science-Media (Pro), “'Earth Girl 2: Tsunami” a casual strategy game, 5-min demo,” 2013. https://vimeo.com/88034086 (accessed Sep. 28, 2020).

[83] I. Kerlow, G. Pedreros, and H. Albert, "Earth Girl Volcano: Characterizing and Conveying Volcanic Hazard Complexity in an Interactive Casual Game of Disaster Preparedness and Response," Geosci. Commun., pp. 1-24, 2020. Available: https://doi.org/10.5194/gc-202016.

[84] PreventionWeb, "Tanah: The Tsunami and Earthquake Fighter - A Mobile App Helping Kids Be Prepared!," Educational Material. https://www.preventionweb.net/educational/view/47238 (accessed Sep. 28, 2020).

[85] A. S. Harnantyari et al., "Tsunami awareness and evacuation behaviour during the 2018 Sulawesi Earthquake tsunami,” Int. J. Disaster Risk Reduct., vol. 43, no. November 2019, 2020, doi: 10.1016/j.ijdrr.2019.101389.

[86] A. V. Gampell, J. C. Gaillard, M. Parsons, and K. Fisher, "Beyond Stop Disasters 2.0: an agenda for exploring the contribution of video games to learning about disasters," Environ. Hazards, vol. 16, no. 2, pp. 180-191, 2017, doi: 10.1080/17477891.2016.1275502.

[87] Y. Bachvarova, S. Bocconi, B. Van Der Pols, M. Popescu, and I. Roceanu, "Measuring the effectiveness of learning with serious games in corporate training," Procedia Comput. Sci., 
vol. 15, no. 0, pp. 221-232, 2012, doi: 10.1016/j.procs.2012.10.074.

[88] A. Smidt, S. Balandin, J. Sigafoos, and V. A. Reed, "The Kirkpatrick model: A useful tool for evaluating training outcomes," J. Intellect. \\& Dev. Disabil., vol. 34, no. 3, pp. 266-274, 2009, doi: 10.1080/13668250903093125.

[89] P. Backlund and M. Hendrix, "Educational games - Are they worth the Effort?: A literature survey of the effectiveness of serious games," 2013 5th Int. Conf. Games Virtual Worlds Serious Appl. VS-GAMES 2013, no. December, 2013, doi: 10.1109/VSGAMES.2013.6624226.

[90] P. Meera, M. L. McLain, K. Bijlani, R. Jayakrishnan, and B. Rao, "Serious Game on Flood Risk Management,”2016, pp. 197-206. https://doi.org/10.1007/978-81-322-2553-9_19.

[91] A. De Gloria, F. Bellotti, and R. Berta, "Serious Games for education and training," Int. J. Serious Games, vol. 1, no. 1, 2014, doi: 10.17083/ijsg.v1i1.11.

[92] D. B. Clark, E. E. Tanner-smith, and S. S. Killingsworth, "Digital Games, Design , and Learning: A Systematic Review and Meta-Analysis," Rev. Educ. Res., vol. 86, no. 1, pp. 79-122, 2016, doi: 10.3102/0034654315582065.

[93] E. Braad, G. Žavcer, and A. Sandovar, "Processes and models for serious game design and development," Lect. Notes Comput. Sci. (including Subser. Lect. Notes Artif. Intell. Lect. Notes Bioinformatics), vol. 9970 LNCS, no. October, pp. 92-118, 2016, doi: 10.1007/9783-319-46152-6_5.

[94] A. Alexiou, "Digital game elements, user experience and learning: A conceptual framework," Educ inf Technol, vol. 23, pp. 2545-2567, 2018, doi: https://doi.org/10.1007/s10639-018-9730-6 Digital.

[95] A. Amory, "Game object model version II: a theoretical framework for educational game development," Educ. Technol. Res. Dev., vol. 55, no. 1, pp. 51-77, 2007, doi: 10.1007/s11423-006-9001-x.

[96] S. Arnab et al., "Mapping learning and game mechanics for serious games analysis," Br. J. Educ. Technol., vol. 46, no. 2, pp. 391-411, 2015, doi: 10.1111/bjet.12113.

[97] A. Patino, M. Romero, and J. Proulx, "Analysis of Game and Learning Mechanics according to the Learning Theories," in VS-Games 2016, 2016, no. September, doi: 10.1109/VSGAMES.2016.7590337.

[98] B. B. Marklund, "Out of Context - Understanding the Practicalities of Learning Games," in Proceedings of DiGRA 2014 Conference, 2014, pp. 1-16. Available: http://www.digra.org/wp-content/uploads/digital-library/digra2014_submission_92.pdf.

[99] B. B. Marklund and A. A. Taylor, "Educational Games in Practice: The challenges involved in conducting a game-based curriculum," Electron. J. e-Learning, vol. 14, no. 2, pp. 122 135, 2016.

Available: https://academic-publishing.org/index.php/ejel/article/view/1749/1712.

[100] D. Dicheva, C. Dichev, G. Agre, and G. Angelova, "Gamification in Education: A Systematic Mapping Study," Educ. Technol. Soc., vol. 18, no. (3), pp. 75-88, 2015. Available: https://www.researchgate.net/publication/270273830_Gamification_in_ Education_A_Systematic_Mapping_Study.

[101] B. Marne, J. Wisdom, B. Huynh-Kim-Bang, and J.-M. Labat, "The Six Facets of Serious Game Design: a Methodology Enhanced by our Design Pattern Library,” in 21st Century Learning for 21 st Century Skills, vol. 7563, no. September, Saarbrücken, 2012, pp. 208-221. https://doi.org/10.1007/978-3-642-33263-0. 
[102] S. P. A. S. Felicio et al., "Stop disasters game experiment with elementary school students in Rio de Janeiro: Building safety culture," in ISCRAM 2014 Conference Proceedings - 11th International Conference on Information Systems for Crisis Response and Management, 2014, no. May, pp. 585-591. Available:

https://www.researchgate.net/publication/298069702_Stop_Disasters_Game_Experiment_ with_Elementary_School_Students_in_Rio_de_Janeiro_Building_Safety_Culture.

[103] K. A. N. L. Ariandini, "The Effect on Education Based on Android Games of Conversion of Tsunami and Earthquakes," Denpasar Health Polytechnic, 2019. Available http://repository.poltekkes-denpasar.ac.id/2435/.

[104] E. W. Winarni, E. P. Purwandari, and W. Wachidi, "The effect of android-based earthquake game toward Bengkulu City elementary school student's knowledge about earthquake disaster preparedness," J. Phys. Conf. Ser., vol. 1731, no. 1, 2021, doi: 10.1088/17426596/1731/1/012090.

[105] International Federation of the Red Cross and Red Crescent Societies; Save the Children International, "Public Awareness and Public Education for Disaster Risk Reduction," Geneva, 2018. Accessed: Nov. 15, 2020. Available: https://media.ifrc.org/ifrc/messagesdisaster-prevention/\#3.

[106] A. Gampell, J. C. Gaillard, M. Parsons, and L. Le Dé, “'Serious’ Disaster Video Games: An Innovative Approach to Teaching and Learning about Disasters and Disaster Risk Reduction," J. Geog., vol. 119, no. 5, pp. 159-170, Sep. 2020. doi: 10.1080/00221341.2020.1795225.

[107] D. King, P. Delfabbro, and M. Griffiths, "Video Game Structural Characteristics : A New Psychological Taxonomy,” pp. 90-106, 2010, doi: 10.1007/s11469-009-9206-4. 